\title{
A dance of empowerment - lessons for the NHI?
}

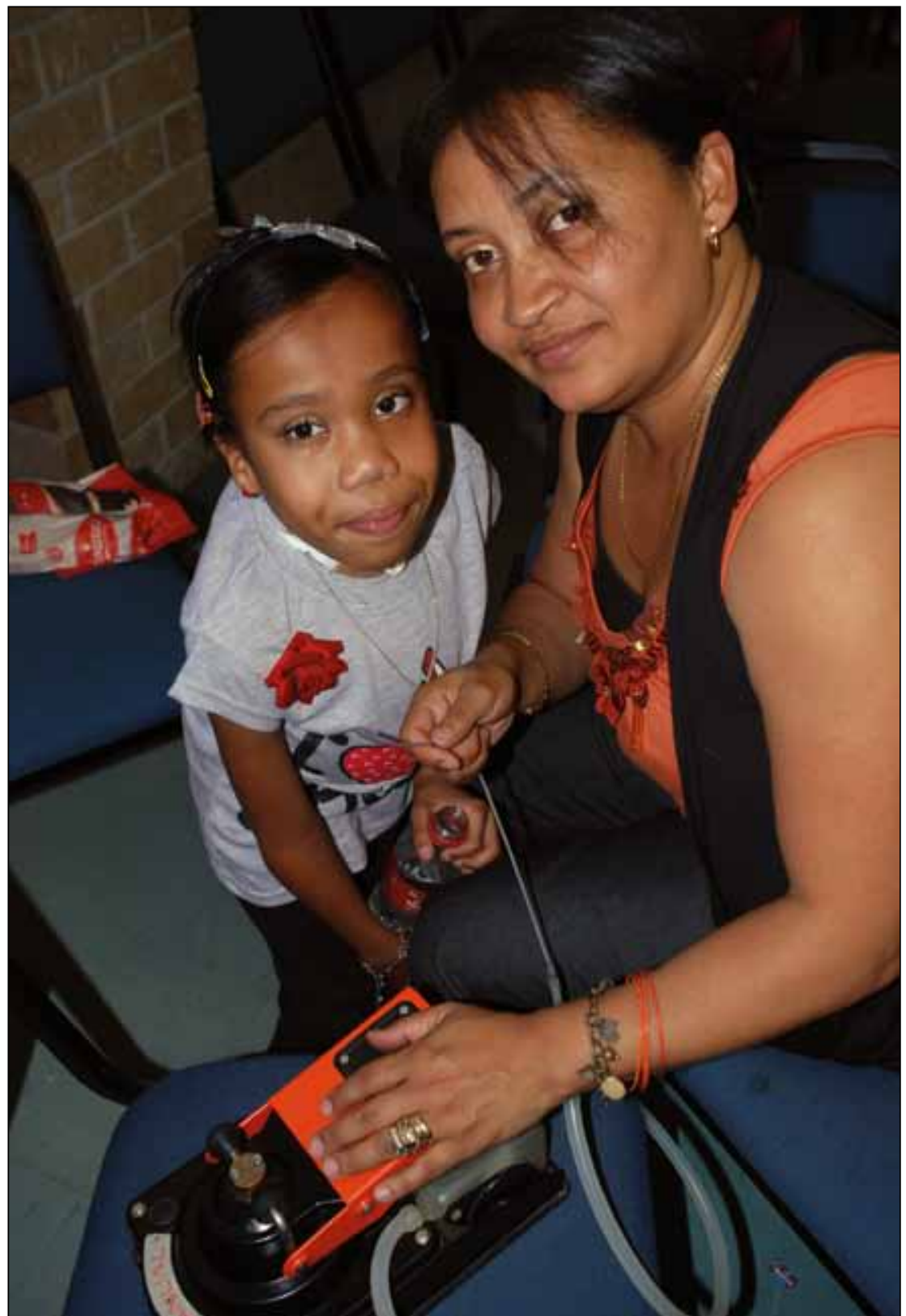

Nikita and her mom Berenice prepare to use the manual suction pump to help clear her lungs.

Picture: Chris Bateman

The audience watches spellbound as Nikita Scott, 11, of Mitchells Plain, twirls to the music, her wizened little body lost in a transcendent performance of 'spiritual dancing', rendering near-invisible her musculoskeletal disorder and attendant tracheostomy tube.

It's the annual tea party for tracheostomised children at Red Cross War Memorial Children's Hospital in Mowbray, Cape Town, and there's additional entertainment: a magician, face-painting, singing by Bishops Junior Boys School choir and delicious food. Each of the scores of 'trache' children tracking 131 trache children (119 in the home care programme, of whom 26 were living in shacks, 53 in sub-economic houses and 40 in their 'own' homes) reveals an 8.18 times greater risk of dying in an institution than at home, with trache outpatients only admitted (unscheduled) on average less than once per child per year. The cost-saving to the Children's Hospital is the equivalent of running 10 hospital wards of 28 beds each for a year. The children no longer have to suffer the proven adverse effects of long-term hospitalisation (e.g. emotional deprivation, cultural isolation and health hazards), while thinly spread and overworked hospital staff are freed of the extra pressure created by often highly active little patients.

\section{Each of the scores of 'trache' children and their families have different, stark stories of courage, endurance and triumph over adversity, but all share something unique: they are outpatients.}

The 'take home' lessons for the revamped community-orientated primary health care approach now underpinning preparations for South Africa's National Health Insurance (NHI) are profound, as is the patient empowerment and inter-sectoral collaboration so essential for success.

Professor Max Klein (partially retired), former Respiratory Intensive Care Unit and Pulmonology chief at the Children's Hospital, and Sister Jane Booth, the advanced paediatric clinical nurse practitioner who co-ordinates the tracheostomy and ventilation home care programme, ran the study together. The Hospital's nursing administrator, Ms D M MacWilliams, was among the first to see the need to bolster the care of trache children and agreed to allocate an enthusiastic Booth exclusively to the ICU. Later (in 1988) MacWilliams traded Booth's request to work part-time (to look after her own newborn) for 'standardisations and co-ordination' of all 25 of the Hospital's trache kids.

This so boosted Booth's confidence and experience with trache children that Klein agreed that she expand into formal home care where, by partnering with social worker, Mrs Sheila Berger, she soon realised that shack dwelling and other low-income parents living without running water or electricity were more than up to the task. Their single biggest (and life-saving) innovation was teaching mothers to change the tracheostomy tube 
every day instead of attending hospital to have the tube changed for them by doctors weekly or even monthly as was (and still is) common practice worldwide, often in FirstWorld settings.

\section{Their single biggest (and life-saving) innovation was teaching mothers to change the tracheostomy tube every day instead of attending hospital to have the tube changed for them by doctors weekly or even monthly as was (and still is) common practice worldwide, often in First-World settings.}

\section{Missing the basics ...}

A life-threatening and sometimes fatal buildup of secretions inside the tracheostomy tube can cause blockages - something so basic that one First-World delegate at a paediatric critical care conference in Geneva in 2007 approached Booth in tears after her presentation. 'She said she wasn't crying for the poor children in Africa but in disbelief that she and her colleagues in the First World hadn't got to the standards we have.' Booth gave the example of a trache child being discharged from a city hospital in the UK to a distant suburb where every relevant specialist in the NHI district was alerted in advance of the discharge, versus the far simpler but equally carefully prepared system of predominantly maternal home care in Cape Town.

Bed pressure at the Children's Hospital became so bad that a 50-bed ward was built on the City Hospital site near Green Point -25 beds for the Children's Hospital and 25 for Tygerberg Hospital - exclusively for trache children. However, it was never commissioned because by the time it was completed it was no longer needed, so successful was the home care programme.

Klein and Booth's growing number of professional students are thoroughly convinced that empowerment underpins the home care programme's myriad benefits and see it as the single most important principle in rehabilitation. The children may be 'technology dependent', but the mothers are in Klein's words 'the most sophisticated technology available in the world; love is of more consequence to the child than physical comfort; intelligence is not related to literacy and the best care is not necessarily the more costly care. Booth relates how one of her early home care patients came back to the clinic for a check-up and 'held onto his father for dear life', scared that he would be kept at hospital, revealing the impact of institutionalisation.

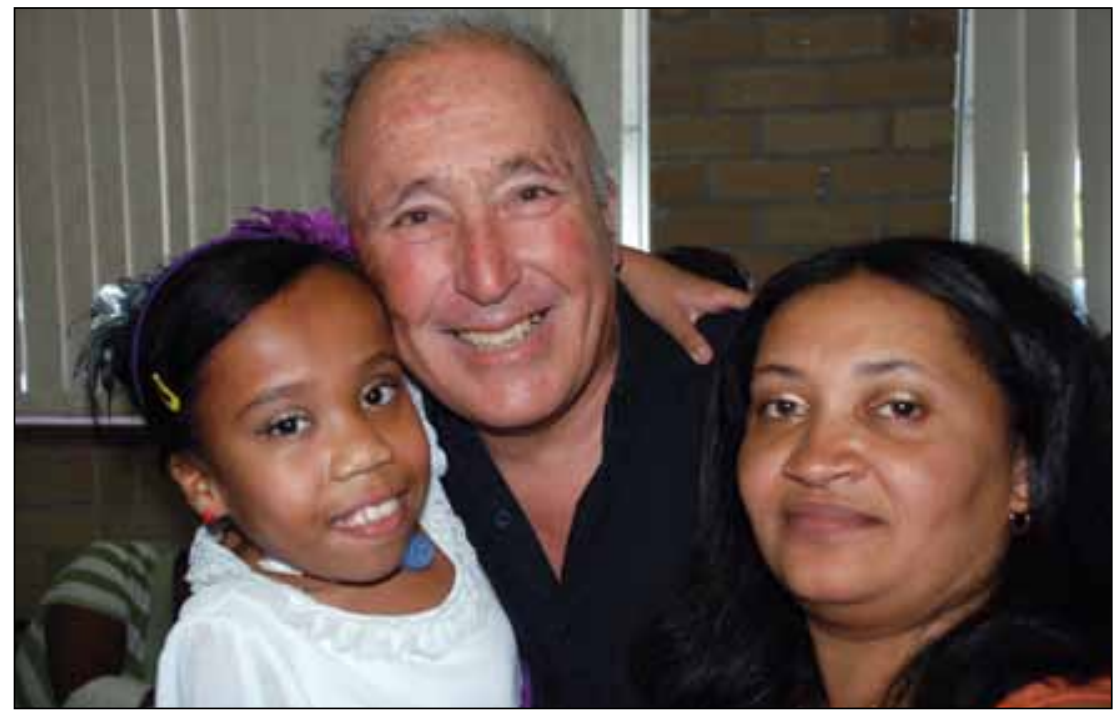

Nikita Scott, 11, of Mitchells Plain, with her mother, Berenice, and paediatrician Professor Max Klein.

Picture: Chris Bateman

How tracheostomy home care works The Cape Town Tracheostomy Home Care Programme works like this: Once the predisposing condition is stabilised and under control, the parents (mostly mothers) are given the knowledge and skills to care for their technology-dependent child by a multidisciplinary team of healthcare workers, a thorough test run on hospital grounds, and then allowed home bearing a mechanical suction pump and accessories. Some children need home ventilation, which requires more expensive and sophisticated equipment for the families to master. Sister Booth's cell phone number is part of the home-care package - she makes herself available around the clock.

The degree of independence some children have achieved is startling and puts the lie to doctor and nurse behaviour that

\section{The children may be 'technology} dependent', but the mothers are in Klein's words 'the most sophisticated technology available in the world; love is of more consequence to the child than physical comfort; intelligence is not related to literacy and the best care is not necessarily the more costly care'.

Booth describes as 'professional paternalism'.

Nikita, who through force of circumstance attends a school for children with physical disabilities and cerebral palsy in Mitchells Plain, carries three schoolbags - one for an electric suction pump (so as not to disturb the teachers and other pupils), one for her manual suction pump (for use on the bus
The degree of independence some children have achieved is startling and puts the lie to doctor and nurse behaviour that Booth describes as 'professional paternalism?

trip), and another for school books. Last year she won a certificate for being a role model at the school and several competitions simply for doing her 'favourite things in all the world'- modelling and dancing. Berenice, her proud mother of three (brother Keanan, 5, and sister, Kayla, 17), confesses that she broke down in tears when she unexpectedly found Nikita delighting in a dance class. She had previously dissuaded her for purely selfconscious reasons: 'Right there and then my own insecurities were broken; she loved it ... it's helped her posture and is great exercise,' she admits.

\section{Taking life one breath at a time}

The Scott family have learnt to take life one breath at a time - Nikita nearly died three times (blockages). Her arrival in the world was itself a miracle, a footling breech delivery that prevented an emergency C-section and robbed her of oxygen, an arm broken and a critically low initial Apgar score. Her mom tells of subsequent surgery to repair a cleft palate and prevent reflux, contracting pneumonia (from milk in her lungs) - all at 3 months old. Soon afterwards somebody felt 'something strange about her back - it was her spine bent to the left' (kyphoscoliosis). A 16-hour surgical repair at 12 months old was only partially successful and put Nikita in ICU for 3 months, where a daylong experiment with a spinal 'straight- 
jacket' merely aggravated her breathing problems and hastened a tracheostomy and ventilation. Nikita was slowly weaned off day-time ventilation and eventually night ventilation as well.

'It wasn't easy getting her to where she is now ... we've helped her realise she's different but still capable - anything can happen, but at least now our mindsets are right and we can cope, thanks to all the inspiration and support we've had,' says a grateful Berenice.

Reece Jordan Kayser, 2, of Retreat, was born with a hereditary condition that left him with a split palate (his mother, maternal aunt and cousin all had variations), resulting in his tongue falling back and blocking his airway (forced to sleep on his stomach before the tracheostomy). He's been in and out of hospital from birth until about 5 months ago. Mother Rowena says of the portable manual suction pump: 'It's given me my child back' - not to mention her sales consultant job which she quit for a year. 'If we go anywhere, the first thing he does is run for his pump, the machine goes with us everywhere.'

Reece is at an 'ordinary' crèche where Rowena has trained a staff member to help him with his pump and general medical care. 'He's quite fine at night; it's just this summer weather that turns the mucus hard, so things tend to clog up and it can be dangerous. But we've had no scares at home (versus previously at the hospital where he twice nearly died from upper airway obstruction - luckily Sister Jane was there to save him. The prognosis for Reece is excellent and his tracheostomy temporary.

\section{Mother Rowena says of the} portable manual suction pump: 'It's given me my child back' - not to mention her sales consultant job which she quit for a year.

Trache patient eligible for world record?

Perhaps the best-known Children's Hospital trache story is that of Eugene Murphy, now 34 , who suffered a severe spinal cord injury when knocked down by a car at 8 years old, damaging his respiratory muscles and forcing him to use a mechanical ventilator to breathe when asleep. His respirator deteriorated after years of use and Victoria Hospital ICU nursing sister Corrie Collins contacted the Carte Blanche television show staff who promptly aired his life story, inspiring a fund which has helped both him and half a dozen other trache children since. The Children's Hospital crew secured mechanical ventilation for him at home
Eugene is now married with children and still needs mechanical ventilation for $8-12$ hours a day, facts that Klein believes make him eligible for the Guinness Book of Records.

'As far as I know he is the only ventilatordependant person in the world to have married and had children,' says Klein, who cites other contenders as Professor Stephen Hawking (tracheostomy in 1985), actor Christopher Reeve (the original Superman movie hero) ( survived 9 years on domiciliary mechanical ventilation), and Martha 'Sunny' von Bulow, 'murder mystery' heiress, who died in December 2008 after 30 years in a persistent vegetative state.

The individual stories are inspiring, but it's the gradual take-up of the tracheostomy team's work at the Children's Hospital (where many paediatric registrars were inspired by the trache home care programme) that deserves centre spot on the radar of national health planners.

\section{According to calculations made by Dr Sue Harris, a senior} specialist at the Pietermaritzburg Metro Hospital Complex, by supporting an average of 10 trache children at home over the last 4 years, her team has saved her health department $\mathrm{R} 41$ million in today's terms.

\section{Slow ripple effect}

Efficacy, cost-efficiency, empowerment these words were repeated by Booth and two paediatricians she's mentored, now working in KwaZulu-Natal, who've persuaded their superiors to breathe life into similar programmes in Pietermaritzburg and Durban. According to calculations made by Dr Sue Harris, a senior specialist at the Pietermaritzburg Metro Hospital Complex, by supporting an average of 10 trache children at home over the last 4 years, her team has saved her health department R41 million in today's terms. Adds her colleague, Dr Shivani Singh, paediatric critical care specialist at Nkosi Albert Luthuli Central Hospital in Durban, it's 'an absolute travesty that such programmes are not funded nationally'.

'Jane has been doing it for ages and here we are now doing it without government support and relying on NGOs, the private sector and philanthropists for machines, food and transport money. Talk about how to reduce infant mortality rates! This requires national policy. After a seminal week-long seminar run by Booth (during her annual leave) at Nkosi Albert Luthuli Hospital in October last year, Singh has now secured posts for two

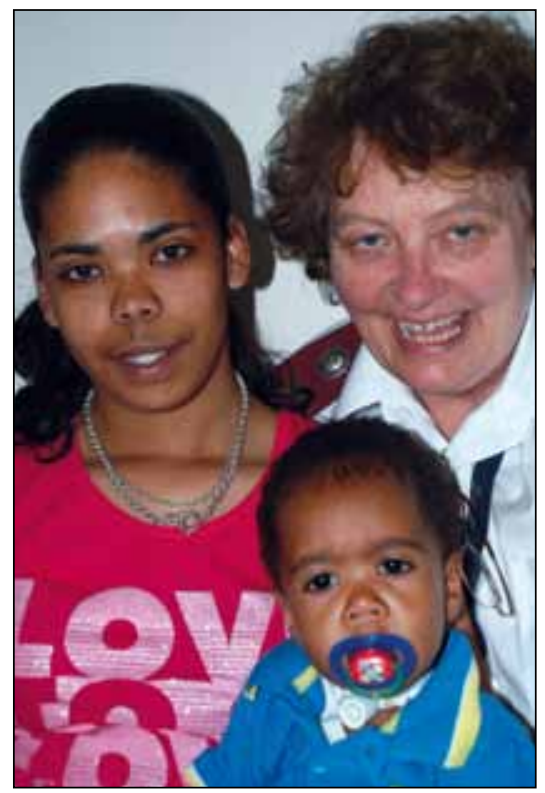

Rowena Pritchard of Ardleigh, Retreat, with her 2-year-old son, Reece Jordan, and Sister Jane Booth at the Children's Hospital.

Picture: Chris Bateman

trache nurses and is setting up a 'train the trainer' nurse and parent home care programme that will eventually have a network at district hospitals and clinics in the tertiary hospital's wide referral area. They currently have 25 children at home on manual suction pumps, with 'huge interest' from paediatric nursing sisters in the deeper rural areas. Pietermaritzburg's Sue Harris has sent 30 tracheostomy children home since October 2007 when Booth helped kick-start their programme, and now has a dedicated nursing sister to co-ordinate full-time. Both paediatricians said they would not have achieved anything without the full backing of their respective hospital superiors and described Booth as 'a national gem'. 'I was frightened of her when I was a registrar at Red Cross,' Harris confessed. Booth's dedication and the need for a multisectoral approach to healthcare can perhaps be summed up by one fairly unique event - she wanted to discharge a young tracheostomy child into the care of his parents at Mfuleni township outside Cape Town, but a preparatory home visit revealed no electricity for his ventilator. A call to a sympathetic Cape Metropole electricity chief, Charles Kadalie, led to the house being connected within a month.

Unusual perhaps, but no less instructive ...

\section{Chris Bateman}

chrisb@hmpg.co.za 